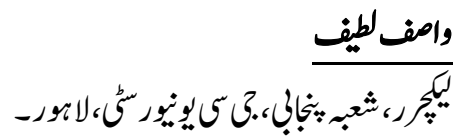

$$
\begin{aligned}
& \text { تواكمُعبرالواجبت تبّم }
\end{aligned}
$$



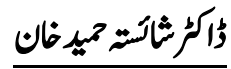



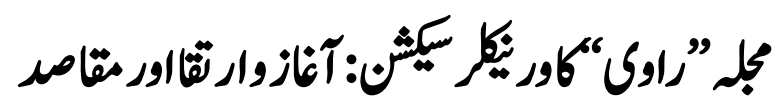

\title{
Wasif Latif
}

Lecturer Department of Punjabi, GC University, Lahore.

\section{Dr. Abdul Wajid Tabassum}

Assistant Professor, Department of Pakistani Languages, Allama

Iqbal open university, Islamabad.

Dr. Shaista Hameed Khan

Assistant Professor, Department of Urdu, GC University, Lahore.

\section{Vernacular section of "Ravi" Magazine (Beginnings, Evolution and Objectives)}

The magazine "Ravi" is very popular annual magazine of Government College Lahore, which is continuously publishing up to date. In the beginning its medium of expression was English. From January 1910 and October 1911 started in Punjabi and Urdu languages respectively. The collective issue of December 1922 and January 1923 started the Vernacular section which lasted till the emergence of Pakistan. Due to the beginning of Vernacular section the regular editorial ship of Urdu and Punjabi (Persian Script) started under which the printing of Punjabi (Gurumukhi) and Hindi became possible. In this way the three Vernacular languages i.e. Hindi, Punjabi and Urdu have been publishing simultaneously. This step facilitated the development of the literature of these three languages. In this article the beginning, development (Evolution) and objectives of the Vernacular section have been discussed to understand the 
pivotal role of the historical magazine "Ravi" for the development of important languages of the Indian Subcontinent.

Keywords: Government College, Lahore, Ravi, Magazine, Vernacular Section, Languages English, Vrdu, Hindi, Punjabi, Gurumukfi, Persian script.

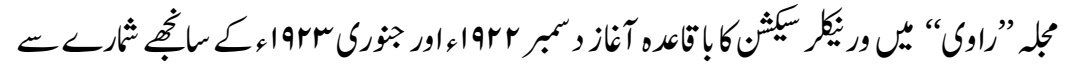

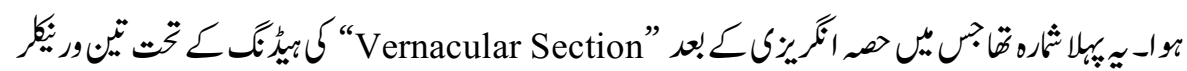

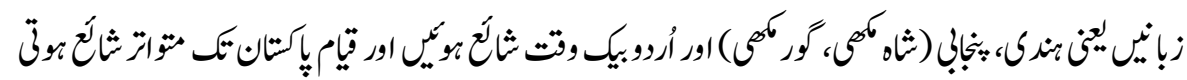

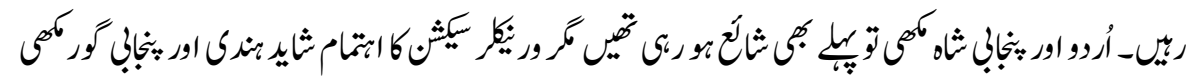

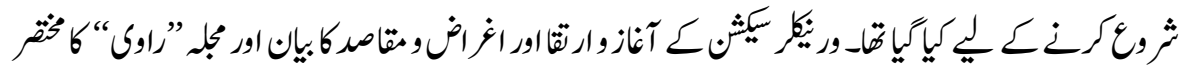
جاءهورجز.

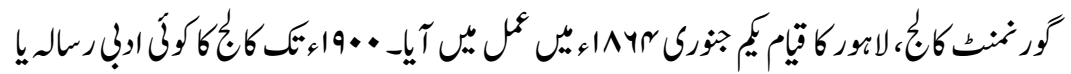

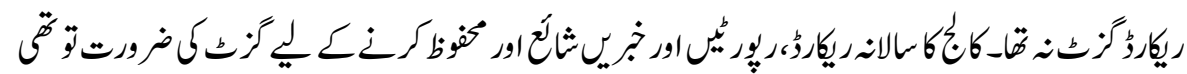



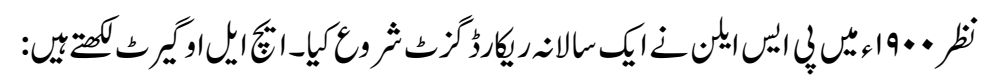

"A college Magazine, confined to records and published annually, was started in June 1900, with Mr. P. S. Allen as editor." (1)

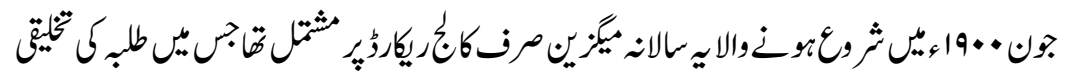

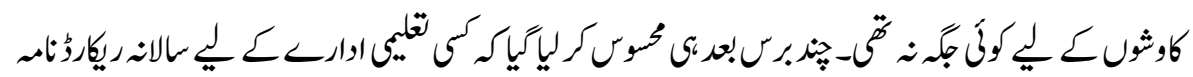

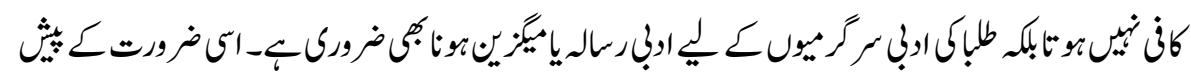

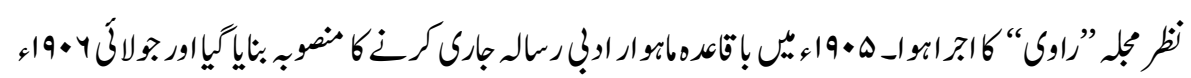

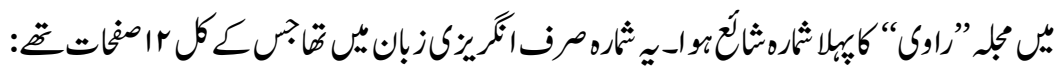


"... In July 1906 was published the first number of "The Ravi"

a monthly Magazine which, under a succession of able and zealous editors, has continued to grow and flourish." (2)



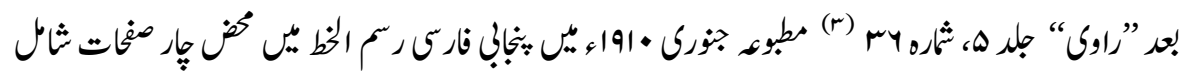

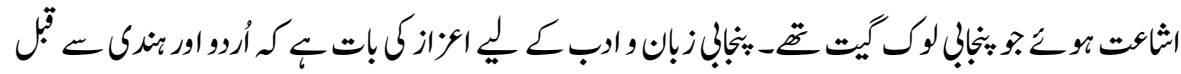

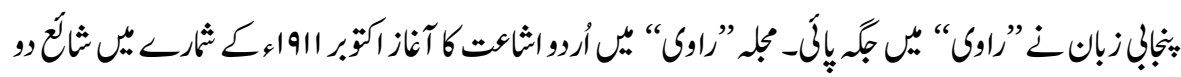



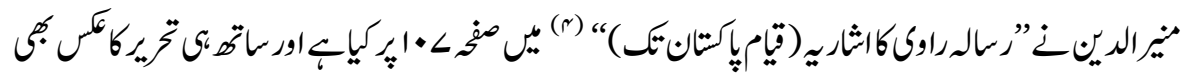

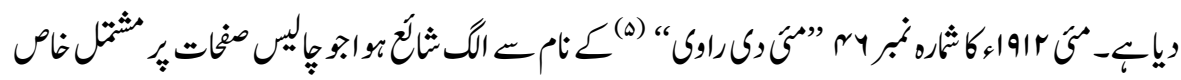

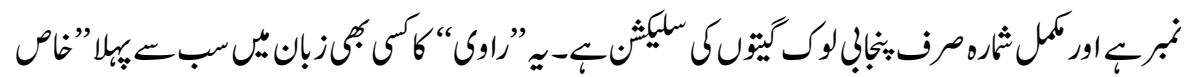
-4 “

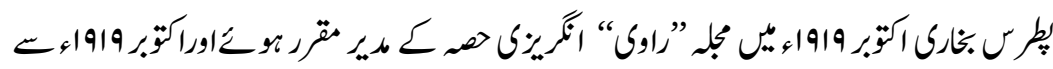

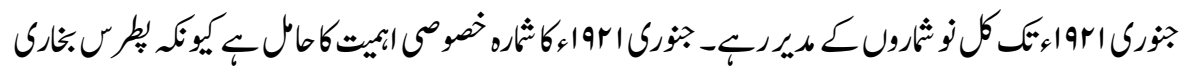

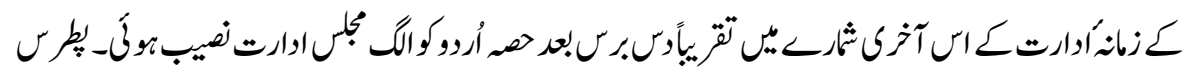

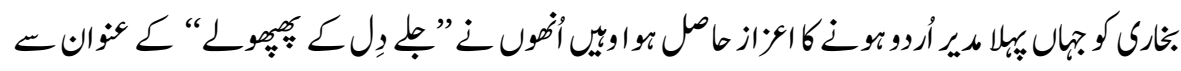

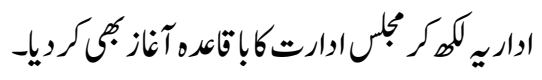

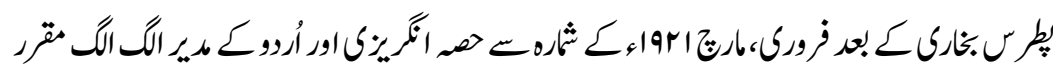

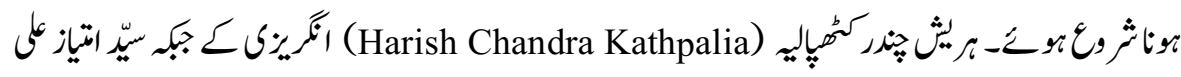

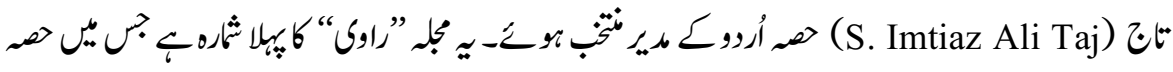



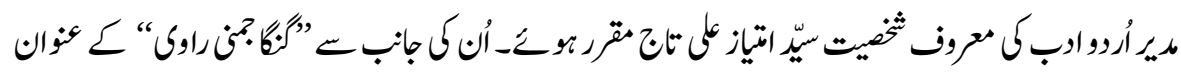

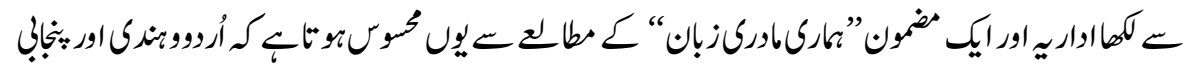




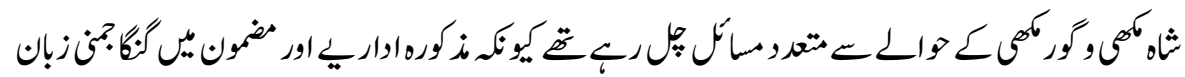



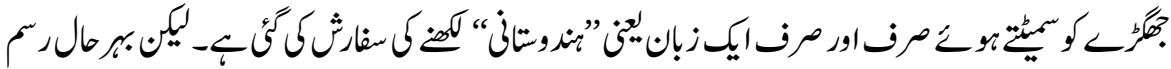

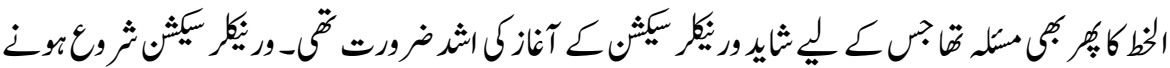



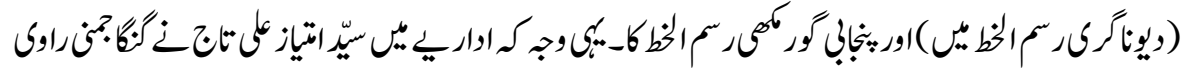



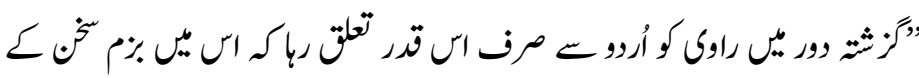

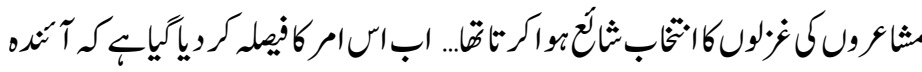

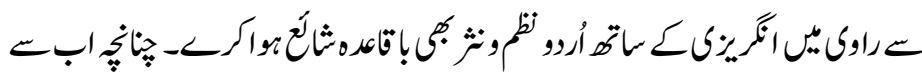

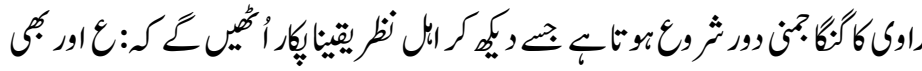

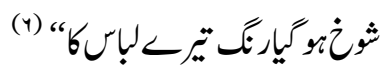

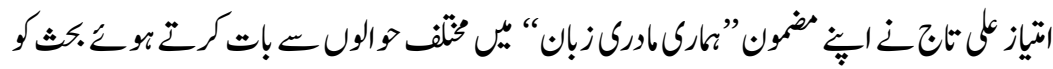

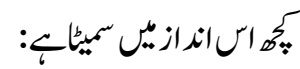

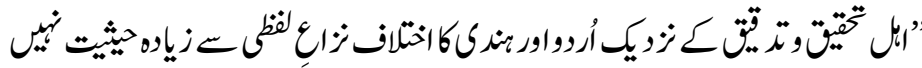

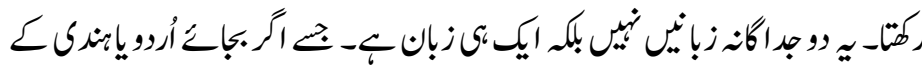

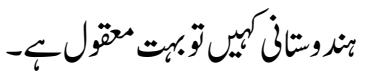

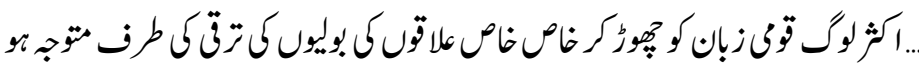

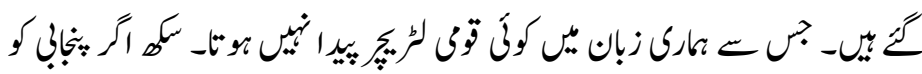

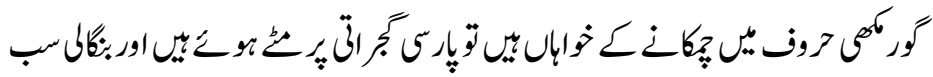

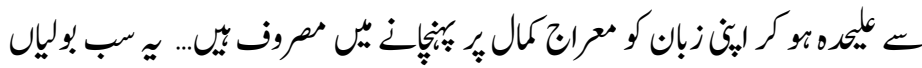

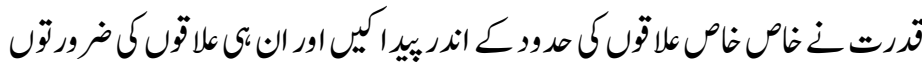

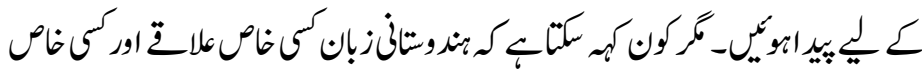




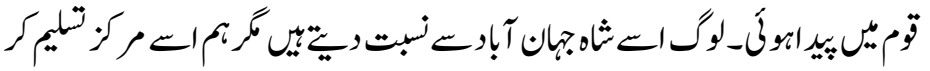

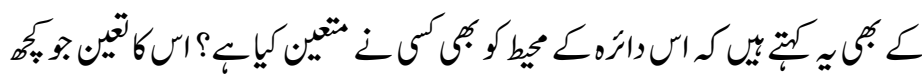

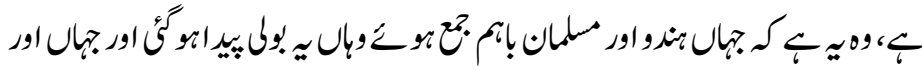

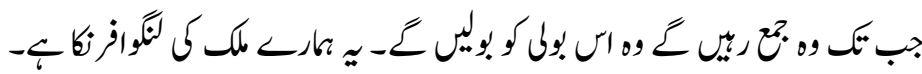

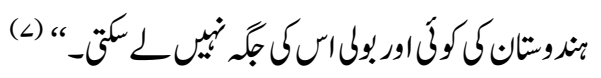

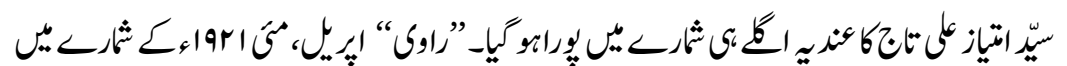

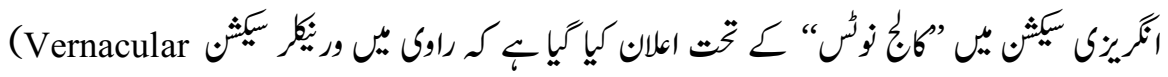

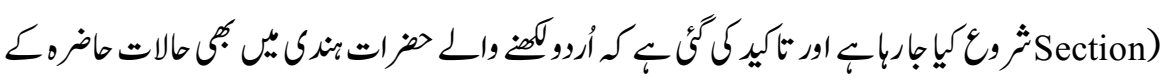

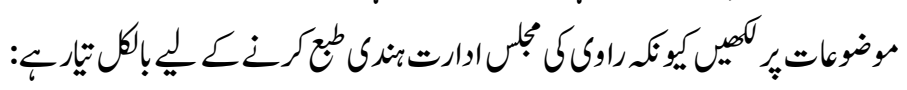

"As is apparent we now devote a considerable portion of our magazine to the vernacular. This is to encourage, in our contributors, the habit of writing in Urdu. We are quite prepared to print Hindi as well, and shall be very glad to receive articles on current topics for insertion in the 'Ravi'. May we make it clear that we are not very anxious to court cheap stuff? We hope our readers will agree that our vernacular section should be 'High class'......." ${ }^{(8)}$

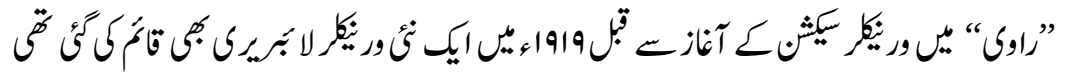

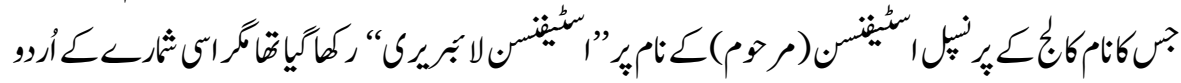

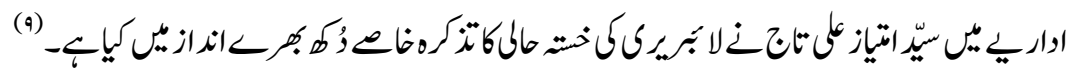

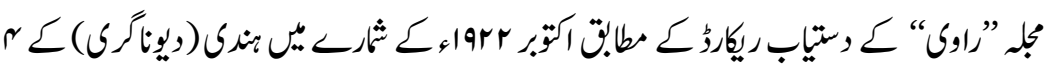


كCuckoo" 




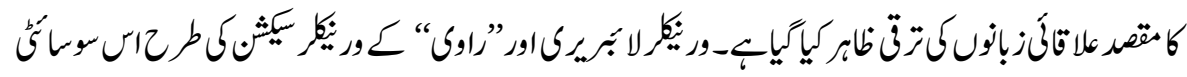



"The Hindi Society_ The want of such a Society was being keenly felt; it has been organized under the president ship of Professor Seth who, we are told, takes great interest in the development of the Hindi language. N. C. Mishra, IV year, has been elected secretary for the year, with Vishwa Mitra, III year, as his assistant." (11)



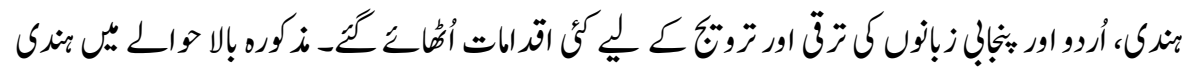

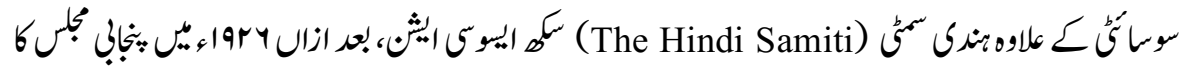

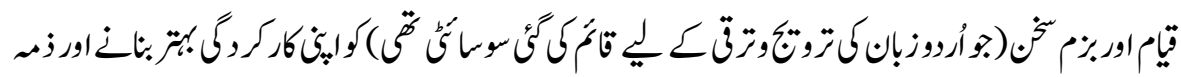

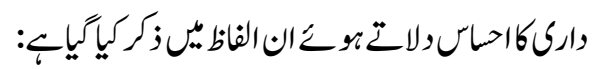

"The Bazm-i-Sukhn_ If English is indispensible, the vernacular is not less so. we hope the all-popular Sh. Fazal Haq, the new secretary will, by an interesting programmed, prove that it is high time we considered the English language and the vernacular as:-

Two sisters gliding in an equal dance.

Two Rivers gently flowing side by side." ${ }^{(12)}$

,

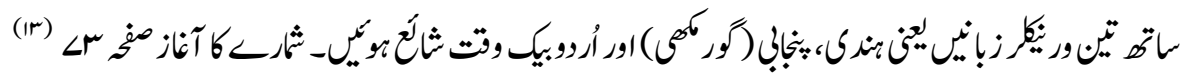




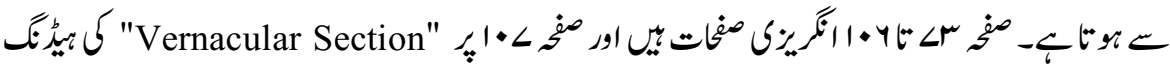

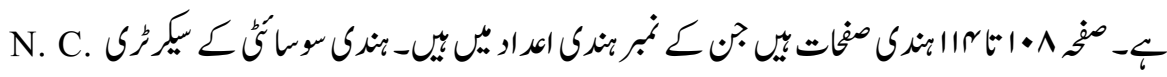
Mishra

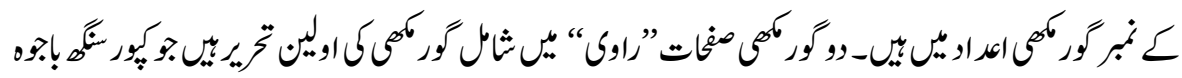

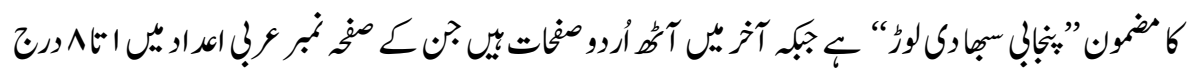

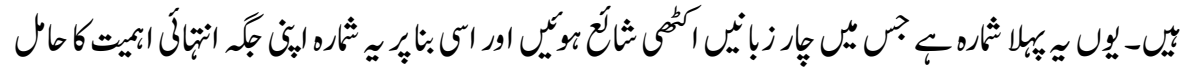

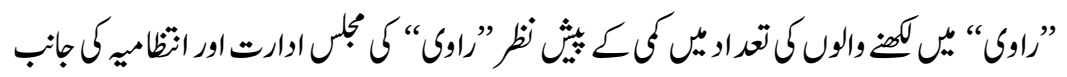

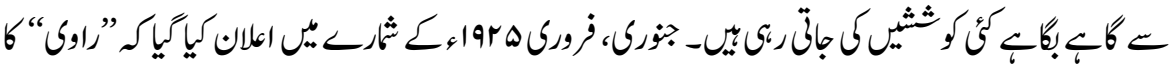

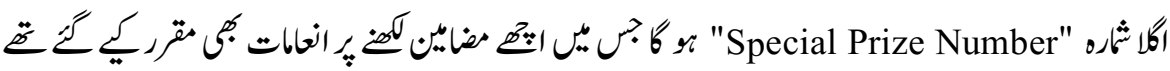



"We have the pleasure to announce that the next number of the Ravi will be a special prize number. There will be four prizes:

(a) Two prizes for the two best articles in English.

(b) One prize for the best articles in Urdu.

(c) One prize for the best articles in Hindi.

The value of the prizes will be announced later on." (14)

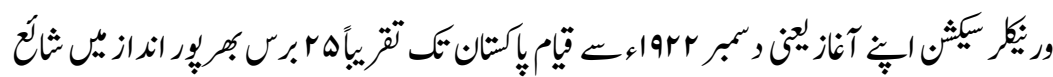

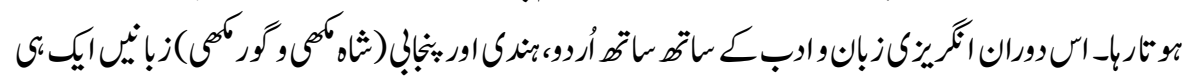




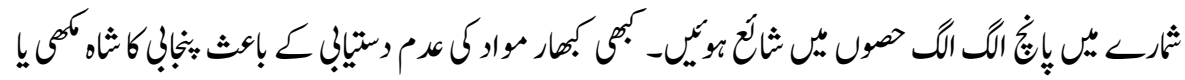

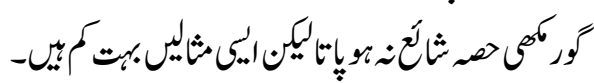

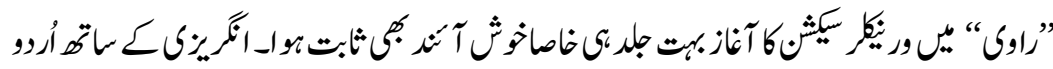

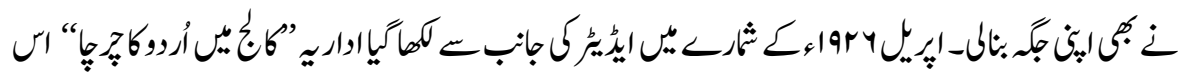

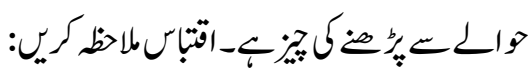

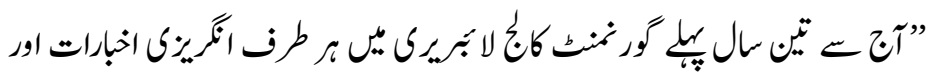

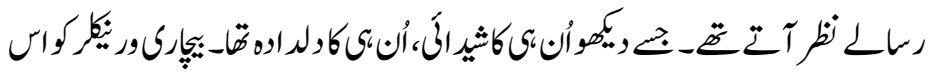

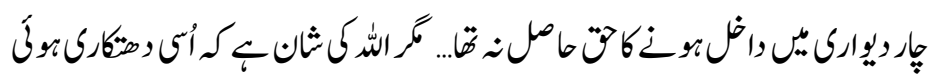

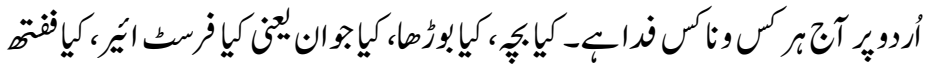

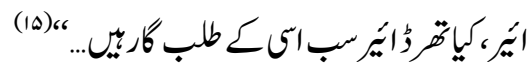

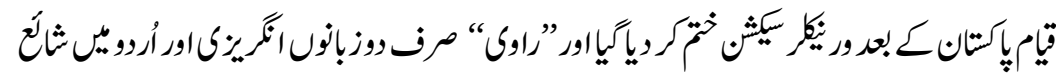

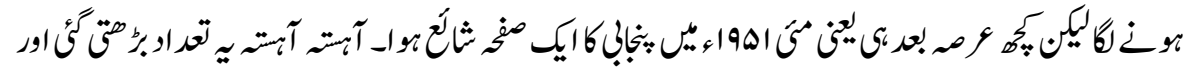

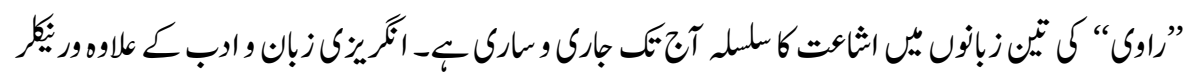

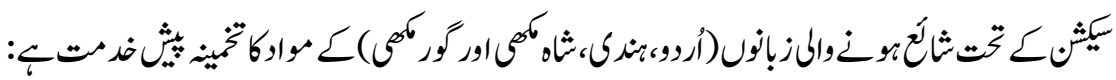



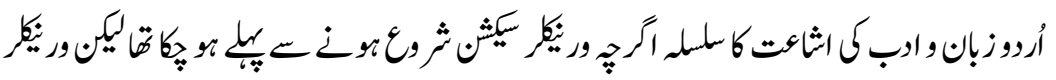

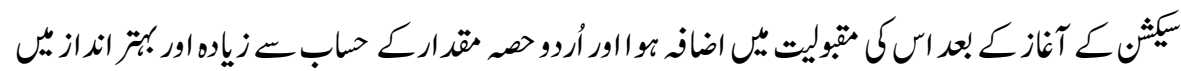

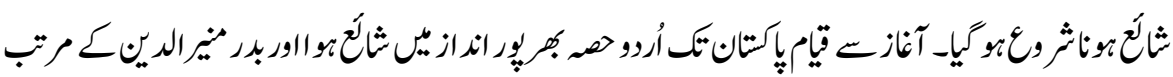

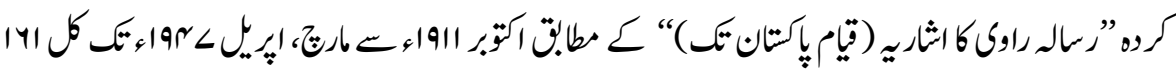

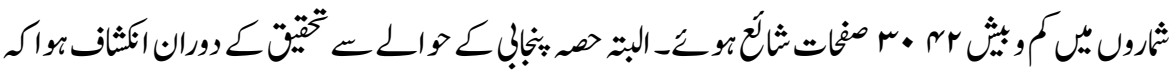

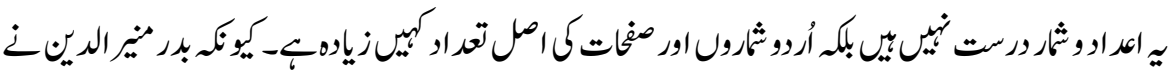

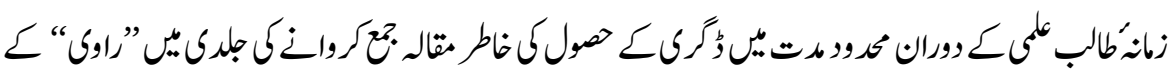




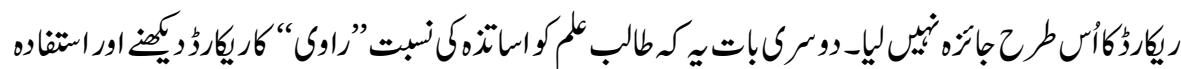

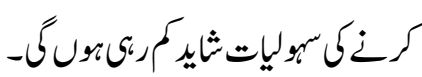

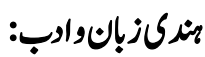

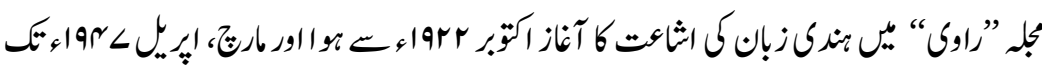



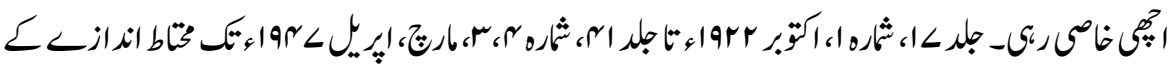

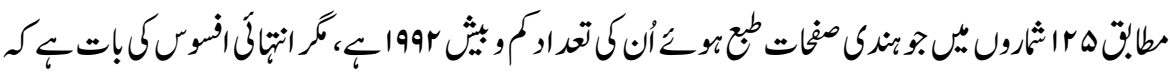

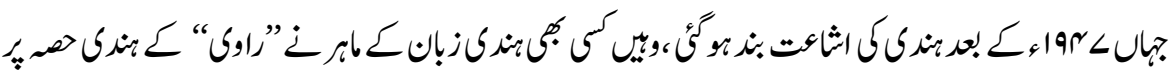



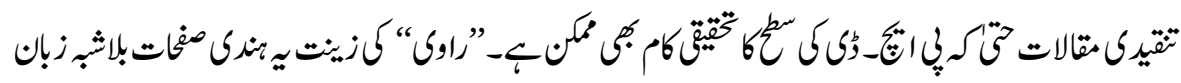



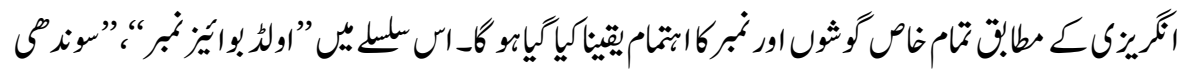

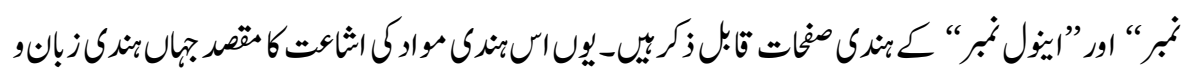



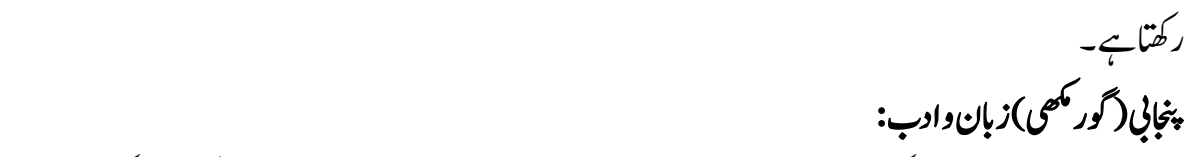

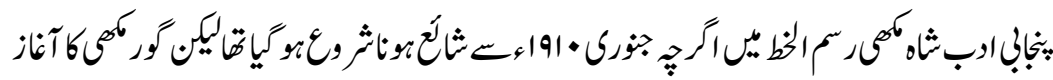

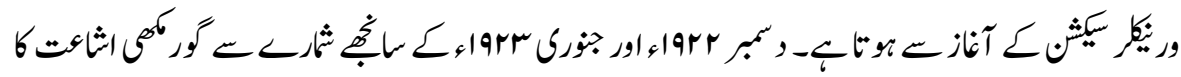

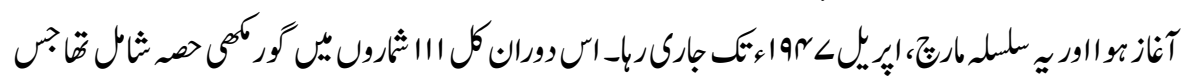

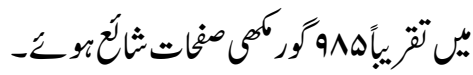

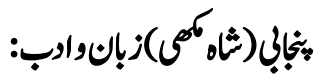

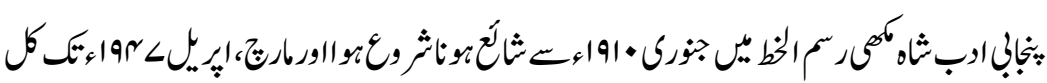

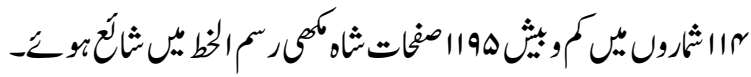








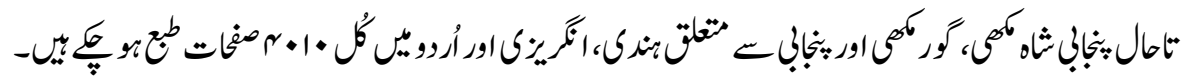



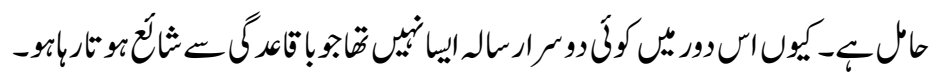

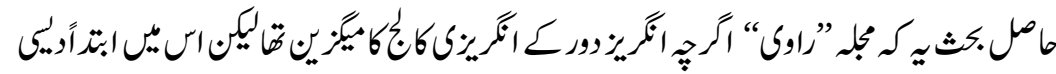

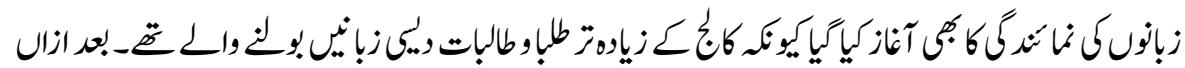

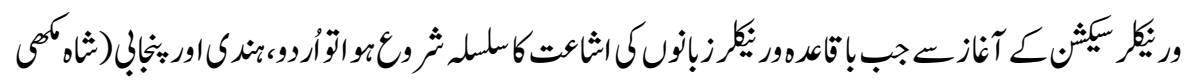

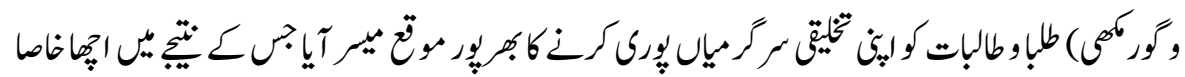

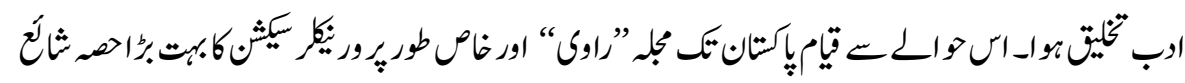

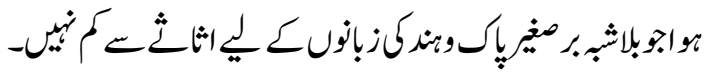
واثَو والرجات

1. A. S. B, "Editorial", The Ravi, Vol: XIII, Issue: 9, October 1919, P: $259-262$

2. A. S. B, "To You" (Editors note), The Ravi, Vol: XIII, Issue: 9, October 1919, P: 269.

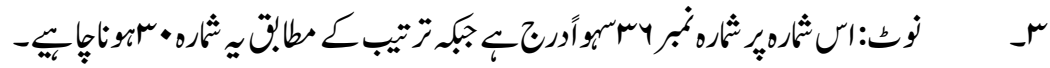

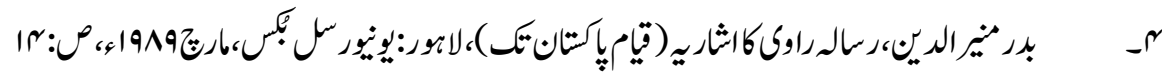

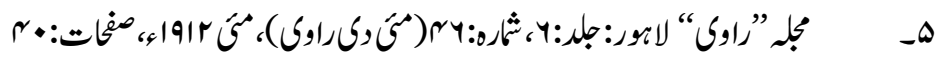

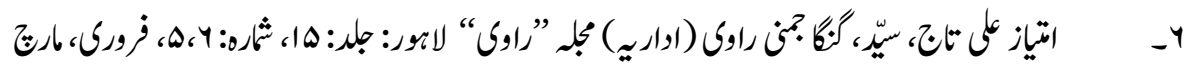
$1: e^{0}, 19 r 1$

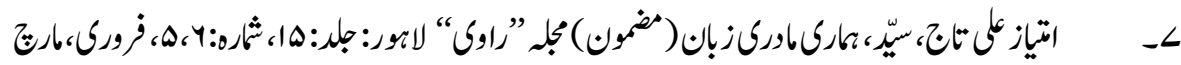
ו 
8. Editor, "College Notes", The Ravi, Lahore: Vol: 15, No: 7,8, April+May, 1921, P. 186.

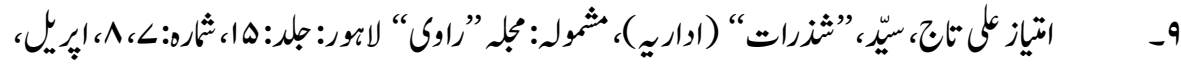

$$
\begin{aligned}
& 1: 0
\end{aligned}
$$

10. Ishwar Das, "To The Cuckoo" (Shakespear's Poem), T he Ravi, Lahore: Vol: 6, No: 43, January, 1912, P. 172.

11. Editor, "Round the College", The Ravi, Lahore: Vol: 17, No: 2, November, 1922, P.68.

12. Editor, "Round the College", The Ravi, Lahore: Vol: 17, No: 2, November, 1922, P.69.

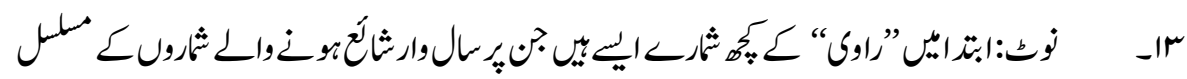

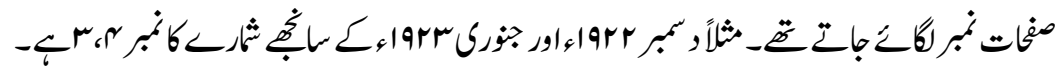

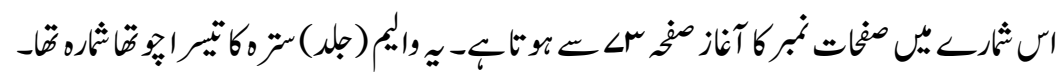

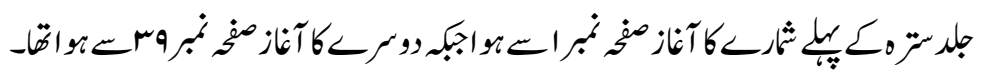

14. K. M. S, "About Ourselves", The Ravi, Lahore: Vol: 19, No: 4, January \& February, 1925, P. 161.

$$
\text { ها- }
$$

